\title{
Factors Influencing Organisation Efficiency of Water Supply and Sanitation Authorities in Tanzania: The Analysis of Mbeya Urban Water Supply Authority
}

\author{
Kelvin Luka Nzilano ${ }^{1 *}$ \\ ${ }^{1}$ Faculty of Business and Information Sciences, Moshi Co-operative University (MoCU), P. O. Box 474, Moshi, Kilimanjaro, \\ TANZANIA
}

\section{*Corresponding Author: kelvinluka@yahoo.com}

Citation: Nzilano, K.L. (2017). Factors Influencing Organisation Efficiency of Water Supply and Sanitation Authorities in Tanzania: The Analysis of Mbeya Urban Water Supply Authority. Aquademia: Water, Environment and Technology, 1(2), 04. https://doi.org/10.20897/awet/75634

Published: December 30, 2017

\begin{abstract}
While Tanzania is endowed with enormous natural water resources, access to clean and safe water remains a great challenge. For instance, out of twenty urban water supply authorities, only three (Arusha, Songea and Tanga) supply water continuously. This paper examines factors influencing organisation efficiency of water supply utilities in Tanzania, using Mbeya Urban Water Supply Authority (UWSA) as case in point. The unit of analysis of this study were all employees of the Mbeya UWSA. Data were collected through structured questionnaires, key informant interviews and documentary analysis. Descriptive analysis and onesample $t$-test were employed as data analysis methods. The findings show that human resource competences in waste water management, civil engineering, distribution of water resources, other industrial services and agricultural water management contributes to a small extent to organisation efficiency of the utility. Shortage of funds, lack of priorities in government budget and low rate of return on investment contributes less to organisation efficiency of the utility. The use of information and communication technology moderately contributes to organisation efficiency while availability of working facilities, engagement in survey and innovation in water management contributes to a small extent to organisation efficiency of the utility. The study recommends Mbeya UWSA to take deliberate efforts to improve the attributes of human resource competences, financial resources and physical resources that have bearing effect on the organization efficiency of the utility in delivering services to customers.
\end{abstract}

Keywords: organisation efficiency, water supply and sanitation authorities, access to water, Tanzania

\section{INTRODUCTION}

The need for improved access to quality water supply and sanitation services is emerging as key objective in poverty alleviation (Van den Berg et al., 2009). Access to improved water supply and sanitation services became more prominent before it was declared in the Millennium Development Goals (MDGs) in 2000. Since then, access to reliable, clean and safe water has remained a global challenge among public water supply utilities especially in developing countries. It is globally estimated that more than 884 million people have no access to improved water, virtually all of them come from developing countries and $84 \%$ of them live in rural area (WHO, 2010). In the SubSaharan Africa, about $61 \%$ of the populations have access to improved water (UNICEF/WHO, 2012) out of which, only 15\% have access to piped water and $48 \%$ use improved water sources (WHO, 2013). Access to safe and clean water is essentially a universal human right since human existence depends on the availability of water. In fact, there is a direct relationship between livelihood and well-being of human beings alongside the supply of clean water. In most countries, the responsibility of water supply is left to the government and is mostly carried 
out by state and monopoly owned organisations (Wallsten and Clark, 2002). In Tanzania for example, the supply of water and sanitation services is a responsibility of autonomous organs known as 'water authorities'.

While organisation efficiency is drawing the attentions of many scholars and practitioners (Tarizka, 2012); the efficiency of water supply utilities in Africa and Tanzania in particular, remains questionable. Most of the water supply utilities fail to provide consumers with adequate water supply (Nickson, 2002). Along the notable challenge, fairly few studies examine the efficiency of water supply utilities as important organs for the survival of human beings. Existing literature shows that factors contributing to inefficiency of water supply utilities includes high non-revenue water, inefficiency in bills collection practices, poorly maintained infrastructures and unaffordable water tariffs particularly by low income earners (Muhairwe, 2009; Mukokoma, 2009; Van den Berg et al., 2009; Mwakalila, 2007). The efficiency of water supply utilities can be examined from the angle of demand and supply. On the demand side, the assessment factors include accessibility and reliability, affordability of services and customer satisfaction. On the supply side, the assessment factors include quality of manpower who provide services, ability to minimize leakages through advanced technology or water-supply facilities and ability to quickly recover water-flow during water-blockage. For reliability and affordability of services, both financial and human capital factors are of significance (Allen, 2008). However, human capital is of vital as it ensures optimal use of financial and physical resources to achieve desired results. Organisation efficiency relates to accurate performance of tasks in an organisation. The goal is to maximize the utility of the available scarce resources to achieve organisation desired objectives (Gopalakrishna, 2012).

\section{LITERATURE REVIEW}

\section{Natural Water Resources and the Status of Water Provision in Tanzania}

Tanzania is one of the countries in the world endowed with enormous natural resources including water resources. For example, in 2008 the country had an estimate of $96.27 \mathrm{~km}^{3}$ per year of renewable water resources compared to world estimated water resources of $43,750 \mathrm{~km}^{3}$ per year (FAO, 2005). Lakes alone are estimated to cover about 7\% of the Tanzania's land surface (Mashauri and Katko, 1993). On the borders, there are three African great lakes such as Lake Tanganyika, Lake Victoria and Lake Nyasa. There are inland lakes such as Lake Rukwa, Lake Eyasi and Lake Manyara. There are also nine major drainage basins divided according to the recipient water bodies namely Nile River, Pangani River, Wami River, Rufiji River and Ruvuma River. Although the country's capacity to supply water stood at $2,266 \mathrm{~m}^{3}$ per person in 2002 , water usage for most municipal water supply utilities in Tanzania mainland remained 493 million $\mathrm{m}^{3}$ per year, equivalent to $0.5 \%$ of total renewable water sources (FAO, 2005).

Moreover, the government enacted a number of reforms towards improving water supply and sanitation services in the country. For example, the establishment of Water Development Policy of 2002 and National Water Sector Development Strategy of 2006 were geared to promote integrated water resources management. Similarly, the government established Urban and Rural Water Supply Authorities (URWSA) and Energy Water Utilities Regulatory Authority (EWURA) in 2006 with the mandate to supply water and sanitation services and regulate the provision of water supply and sanitation services respectively (URT, 2010). However, later on, the responsibility of water supply and sanitation service provision shifted from local government authorities to specific utilities called 'Urban and Rural Water Supply Authorities'. By the end of 2010, there were about 20 urban water utilities, 100 districts water utilities and Community Owned Water Supply Organisations (COWSO) in rural areas (URT, 2010). Despite government initiatives to enhance water availability, access to clean and safe water remains fairly low (URT, 2007). In Dar es Salaam for example, despite heavy investment by international organisations like World Bank and European Union, the utility remains the worst performing water entity (GIZ, 2008).

\section{Previous Studies}

Previous studies jointly found that access to clean and safe water in Tanzania remains a great challenge (Mjindo and Laohasiriwong, 2015; Semberya, 2013; Van den Berg et al., 2009; Mwakalila, 2007; Mashauri and Katko, 1993). For example, in 2002 the availability of renewable water supply stood at $2300 \mathrm{~m}^{3}$ per capita/year and it is estimated to decline to about $1500 \mathrm{~m}^{3}$ per capital/year by 2025 due to population growth (URT, 2002). Similarly, water and sanitation services are generally of low quality with intermittent behaviour (URT, 2009). For example, out of twenty urban water supply and sanitation utilities, only three (Arusha, Songea and Tanga) supply water on continuous basis (URT, 2010). In eleven other regions, the supply of water is at least 19 hours. In Babati and Mtwara, the supply of water is for 12 hours per day. In Dar es Salaam, the supply of water is on average of 9 hours per day. In Kigoma, Lindi and Singida Regions, the supply of water is on average of 5 hours per day (URT, 2010). The above empirical evidences indeed suggest that the supply of water and sanitation in Tanzania is still a great challenge featured with intermittent behaviour. Many utilities can hardly cover their operation and maintenance costs 
through their own revenues due to low tariffs and poor efficiency (Van den Berg et al., 2009). It is in this context that this study was set to examine the internal factors affecting organisation efficiency of urban water and sanitation service providers in developing countries like Tanzania.

With enormous endowment of natural water resources in Mbeya region, one would expect water supply utilities in the region to fall in the category of utilities that supplies water continuously. Contrary, the supply of water remains fairly poor and indeed threatens households' water security (Mjindo and Laohasiriwong, 2015). Although Mbeya UWSA is classified in category ' $\mathrm{A}$ ' of utilities that meet all direct and indirect costs of operations, maintenance and part of infrastructure investment costs (URT, 2002); it does not fall in the category of utilities that supply water and sanitation services continuously (URT, 2010). Against this backdrop, this paper analyses internal factors affecting organisation efficiency of water supply and sanitation service providers in Tanzania, taking Mbeya UWSA as case in point. Mbeya region was selected because it is one the populated regions after Dar es Salaam, Mwanza and Arusha (URT, 2013). Three questions were answered in this paper. First, how do human resource capabilities influence organisation efficiency of water supply and sanitation authorities? Second, how do financial resources influence organisation efficiency of water supply and sanitation authorities? And third, how do physical resources influence organisation efficiency of water supply and sanitation authorities? This paper contributes to the body of knowledge as it provides empirical evidences related to the influence internal factors on organisation efficiency of water supply and sanitation services providers from the Tanzanian perspective.

\section{Conceptual Framework Related to Organisation Efficiency Determinants}

Ndunguru (2007) define conceptual framework as an assemblage of research concepts or variables with their logical relationships represented in diagrams, charts, graphs, pictographs, flow-charts, or mathematical sets. An assessment of existing literature identifies two broad categories of factors that affect organisation efficiency; namely those found outside the organisation and those within the organisation. However, this paper examines internal factors affecting organisation efficiency since they are within the control of an organisation. These factors include human ware or brain ware, hard ware and financial resources. Firstly, human or brain ware includes human resources such as skills, expertise, experience, education, motivation, work environment and conflict of management (Taheri, 1999). In order for human resources to contribute to organization efficiency, employees need to possess skills, experiences and competences necessary for the performance of a particular task at hand. When employees possess relevant competences and experiences, they become more efficient and enhance their productivity and the provision of customer care services. Employees working in water supply utilities are expected to be competent in planning and distribution of water resources, skilled in using water supply facilities, industrial services, agricultural water management and irrigation, among others.

Secondly, hardware or physical resources are very important in enhancing organisation efficiency of any business organisation. They facilitate smooth operations of the activities within the organisation. Physical resources include building and premises, equipments, facilities, plant and machinery, raw materials and wastes (Taheri, 1999). Every business needs physical resources for smooth operations, as such, it is prudent to manage physical resources according to the size, the environment, location and the customer needs and requirements. Absence of modern physical resources and skilled personnel could significantly affect organisation efficiency. Similarly, raw materials are important in order to produce goods and services. When raw materials are not readily available, organisation efficiency remains questionable. Thirdly, financial resources are important ingredients in organisation efficiency as it facilitates the purchase of modern physical resources and other overheads. In Tanzania, the operations of urban water supply authorities depend on grants, donations from donors and government subventions. Organisation efficiency can be affected by shortages and misallocation of funds. To minimise misallocation, integrity among leaders is of paramount important to be emphasised. Organisations will maximise efficiency if top leaders direct financial resources to more productive areas. The pictorial diagram in Figure 1 summarises the key internal factors affecting organisation efficiency in water supply utilities. 


\section{Human resource competences}

- Competence in planning, development and distribution of water resources.

- Competence in waste water management.

- Competence in civil engineering.

- Competence in water pipes and industrial services.

- Competence in agricultural water management and irrigation.

\section{Financial resources}

- Clients connected to water supply.

- Prompt collections of water bills.

- Grants, donors and government subvention.

- Proper use of financial resources.

\section{Physical resources}

- Availability of modern working facilities.

- Use of information and communication in service provision.

- Availability of modern machines and equipment.

- Engagement in survey and innovation
Organisation efficiency

- Improved performance

- Quality service provision

- Minimal loss and leakage

- Reliable access to water

Figure 1. A pictorial diagram of internal factors affecting organisation efficiency

\section{RESEARCH HYPOTHESES}

The study was guided by the following hypotheses:

$\mathbf{H}_{0}$ 1: There is a difference among employees' perceptions with respect to human resource competences to influence organisation efficiency of Mbeya UWSA.

$\mathbf{H}_{0}$ 2: There is a difference among employees' perceptions with respect to financial resources capabilities to influence organisation efficiency of Mbeya UWSA.

$\mathbf{H}_{0}$ 3: There is a difference among employees' perceptions with respect to physical resources capabilities to influence organisation efficiency of Mbeya UWSA.

\section{METHODOLOGY}

The study was carried out in Mbeya UWSA, an autonomous water utility located in Mbeya Region, Southern highlands of Tanzania. The utility was established under section 3(1) of Act No. 8 of 1997 and became fully autonomous with effect on 1st July, 2001 (URT, 2002). Mbeya UWSA is a government agency led by the board of directors under the supervision of Ministry of Water and closely regulated by Water Utilities Regulatory Authority (EWURA). The study employed cross-sectional research design in which data were collected at a single point in time. The design was chosen because it supports a variety of analytical techniques and allows comparisons of many variables at the same time (Katundu and Gabagambi, 2014). Data were collected between February and March, 2015 using self-administered questionnaires, key informant interviews and documentary review. Questionnaires were administered to selected employees to solicit their perceptions on how internal factors such as human resource competences, financial and physical resources influence organisation efficiency of the utility. Key 
informant interviews were administrated to few selected key utility staff. Documentary analysis of related published articles, utility annual reports and ministerial reports were thoroughly analysed as secondary data. A total of 30 respondents were randomly selected from different sections of the utility. Firstly, respondents indicated their perceptions regarding the influence of human resource competences on organisation efficiency of the utility. Questions were structured in such a way that they reflect the extent to which human resources competences influence organisation efficiency of the utility.

Secondly, respondents identified the sources of money used for financing day to day activities of the utility, government subvention directed to the utility yearly, the number of clients connected to water supply and number of clients who currently demand water supply connections and clients already connected. Similarly, respondents indicated their perceptions regarding the efficiency of the utility in collecting water and sanitation bills and its ability to connect clients as projected in the strategic business plan of 2013/2014 and 2015/2016. And thirdly, respondents indicated their perceptions regarding the influence of physical resources capabilities to influence organisation efficiency of the utility. Respondents' perceptions in all measurement constructs were measured by Likert Scale ranging from " $1=$ not at all, $2=$ to a small extent, $3=$ to a moderate extent, $4=$ to a large extent, 5 $=$ to a very large extent". The collected data were then quantitatively analyzed through descriptive statistics and one sample t-test. The decision rule used for testing hypotheses was set to reject null hypothesis and accept alternative hypothesis when $\mathrm{p}$-value score is significant at $\mathrm{p}>0.05$ (Hamilton, 1992). Hence, any coefficient with $\mathrm{p}$-value less than 0.05 were treated as statistically significant.

\section{RESULTS AND DISCUSSION}

The use of parametric statistical methods such as Analysis of Variance (ANOVA) and $t$-test requires all variables be approximately normally distributed. As such, analysis of Shapiro Wilk's test $(\not>0.05)$ (Razali and Wah, 2011) and visual inspection of histogram, normal Q-Q plots and box plots showed that the scores on the five constructs were approximately normally distributed within Z-score of \pm 1.96 (Doane and Seward, 2011) with skewness range of $0.66(\mathrm{SE}=0.42)$ and $1.38(\mathrm{SE}=0.42)$ and Kurtosis range of $0.74(\mathrm{SE}=0.83)$ and $1.31(\mathrm{SE}=0.83)$. Specifically, the scores on human resource competences showed a skewness range of $0.17(\mathrm{SE}=0.42)$ and $1.71(\mathrm{SE}=0.42)$ and Kurtosis range of $0.51(\mathrm{SE}=0.83)$ and $1.39(\mathrm{SE}=0.83)$. Financial and physical resources constructs were normally distributed with skewness range of $0.20(\mathrm{SE}=0.42)$ and $0.53(\mathrm{SE}=0.42)$; Kurtosis range of $0.32(\mathrm{SE}=0.83)$ and $1.09(\mathrm{SE}=0.83)$ and skewness range of $0.20(\mathrm{SE}=0.42)$ and $0.77(\mathrm{SE}=0.42)$; Kurtosis range of $0.20(\mathrm{SE}=0.83)$ and $1.29(\mathrm{SE}=0.83)$ respectively. Following these results, it was justifiable to employ one sample $t$-test as major analysis method because its basic conditions were fulfilled.

First, the study sought to establish the influence of human resource competences on organisation efficiency of Mbeya UWSA. Table 1 summarizes the descriptive results of mean and standard deviation scores of each construct.

Table 1. Mean and standard deviation scores on human resource competences constructs

\begin{tabular}{clccc}
\hline S/No. & Human resource competences & $\mathbf{N}$ & Mean & Standard deviation \\
\hline 1. & Competence in waste water management. & 30 & 3.17 & 0.747 \\
\hline 2. & Competence in civil engineering. & 30 & 2.80 & 0.484 \\
\hline 3. & $\begin{array}{l}\text { Competence in planning, development and distribution } \\
\text { of water resources. }\end{array}$ & 30 & 2.50 & 0.572 \\
\hline 4. & Competence in water pipes and industrial services. & 30 & 2.80 & 0.610 \\
\hline 5. & $\begin{array}{l}\text { Competence in agricultural water management and } \\
\text { irrigation. }\end{array}$ & 30 & 2.77 & 0.430 \\
\hline
\end{tabular}

Table 1 shows that human resource competences in waste water management (3.17), civil engineering (2.8), water pipes and other industrial services (2.8) and agricultural water management and irrigation (2.77) contributes to a small extent in organisation efficiency as they fall above cut-off point of 2.5. This means that employees have confidence that they possess relevant technical competences in waste water management, civil engineering, water pipes and other industrial services and agricultural water management and irrigation. Human resources competences in planning and distribution of water resources had mean score equal to reference mean (2.5). This implies that employees' feels that they lack relevant competences related to planning, development and distribution of water resources. Further analysis were conducted to supplement descriptive results using one-sample $t$-test as summarized in Table 2. 
Table 2. One sample $t$-test on human resource competences and organisation efficiency

\begin{tabular}{|c|c|c|c|c|c|}
\hline \multirow[t]{2}{*}{ S/No. } & \multirow{2}{*}{ Employees' technical competences } & \multicolumn{4}{|c|}{ Test value $=2.5$} \\
\hline & & 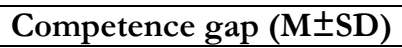 & Difference & T-value & Sign \\
\hline 1. & Competence in waste water management. & $3.17 \pm 0.747$ & .667 & 4.891 & $.000^{*}$ \\
\hline 2. & Competence in civil engineering. & $2.8 \pm 0.484$ & .300 & 3.393 & $.002 *$ \\
\hline 3. & $\begin{array}{l}\text { Competence in planning, developing and } \\
\text { distributing water resources. }\end{array}$ & $2.5 \pm 0.572$ & 0 & 0 & 1.000 \\
\hline 4. & $\begin{array}{l}\text { Competence in water pipes and industrial } \\
\text { services. }\end{array}$ & $2.8 \pm 0.61$ & .300 & 2.693 & .012 \\
\hline 5. & $\begin{array}{l}\text { Competence in agricultural water } \\
\text { management and irrigation. }\end{array}$ & $2.77 \pm 0.43$ & .267 & 3.395 & $.002 *$ \\
\hline
\end{tabular}

Table 2 shows that human resource competences in waste water management, civil engineering and agricultural water management and irrigation were significant at $p<0.05$. This suggests that employees had different perceptions regarding their competences in waste management, civil engineering and agricultural water management and irrigation. This means that employees feel that they possess relevant competences in waste management, civil engineering and agricultural water management and irrigation. There were no difference in employees' perceptions regarding their competences in planning, developing and distributing water resources and other industrial services as their $p$-value score were significant at $p>0.05$. These results are in line with descriptive results with mean scores slightly equal to reference mean of 2.5 (See Table 1). This means that employees lack some technical skills related to planning, development and distribution of water resources. It is a high time for Mbeya UWSA to devise strategies to enhance human resource competences in planning, development and distribution of water resources, water pipes and other industrial services in order to improve the efficiency of the utility. To identify the specific competences which affect employees' competences on the mentioned variables, descriptive analysis were conducted as summarized in Table 3.

Table 3. Mean score on specific employees' competences affecting organisation efficiency

\begin{tabular}{clccc}
\hline S/No. & Specific employees' competences & $\mathbf{N}$ & Mean & Standard deviation \\
\hline 1. & Employees' competences. & 30 & 2.93 & .691 \\
\hline 2. & Career development. & 30 & 2.37 & .556 \\
\hline 3. & Employees' motivation. & 30 & 2.47 & .571 \\
\hline 4. & Personal skills. & 30 & 3.10 & .548 \\
\hline 5. & Employees' attitudes. & 30 & 2.57 & .504 \\
\hline
\end{tabular}

Table 3 shows that employees' competences (2.93) and attitudes (2.57) contributes to a small extent with mean score above reference mean while personal skills (3.10) contributes moderately to organisation efficiency of the utility. This means that employees feel that they possess relevant competences, personal skills and positive attitudes towards work. Previous studies contented that when employees possess relevant competences, skills and attitudes to perform a particular task, organisation efficiency is more likely to be achieved (Gopalakrishna, 2012). On the other hand, employees' career development (2.37) and motivation (2.47) contributes to a small extent to organisation efficiency of the utility with mean score below cut-off point. This means that employees do not feel that the utility have clear plan for their career development and motivation packages. This could significantly affect organisation efficiency as they will lack inner drive to perform hard in order to achieve organisation objectives. In addition, employees have negative attitudes towards works as their mean score was slightly equal to reference mean. Further inferential analysis using one sample $t$-test was employed to identify specific human resource attributes that affect organisation efficiency of Mbeya UWSA.

Table 4. One-sample $t$-test on employees' attributes and organisation efficiency

\begin{tabular}{clcccc}
\hline \multirow{2}{*}{ S/No } & \multirow{2}{*}{ Specific employees' attributes } & \multicolumn{3}{c}{ Test value $=\mathbf{2 . 5}$} \\
\cline { 3 - 6 } & t-value & Df & Sign 2. (tailed) & Mean Difference \\
\hline 1. & Employees' competences. & 3.432 & 29 & $.002^{*}$ & .433 \\
\hline 2. & Career development. & -1.313 & 29 & .199 & -.133 \\
\hline 3. & Employees' motivation. & -.320 & 29 & .752 & -.033 \\
\hline 4. & Personal skills. & 6.000 & 29 & $.000^{*}$ & .600 \\
\hline 5. & Employees' attitudes. & .724 & 29 & .475 & .067 \\
\hline
\end{tabular}


Table 4 shows that employees' competences and personal skills were significant at $p<0.05$. This imply that there is a difference in employee's perceptions regarding the influence of employees' competences and personal skills on organisation efficiency of Mbeya UWSA. This means that employees believe in their personal competences and skills in facilitating organisation efficiency of Mbeya UWSA. The findings are in line with descriptive results with mean score above reference mean (see Table 3). There were no differences in employees' perceptions on career development, motivation and attitudes as their $p$-value scores were significant at $p>0.05$. This mean that employees had negative perceptions on career development, motivational aspects and attitudes towards work in the utility. The study recommends the utility to create good employees' career development, devise incentive mechanisms to boost the declining morale and attitudes toward work. Moreover, employees should be frequently trained through workshops and seminars and pending to the availability of financial resources be sent to pursue further studies. These findings support previous findings which emphasized that in order to boost employees' competences and working morale, organisation should provide employees with good incentive packages and provide education and training through workshops and seminars in order to upgrade their professional competences and skills (Atafar, 2013). It is a high time for Mbeya UWSA to invest in education and training to enhance employees' productivity at workplace (Griliches and Regev, 1995). The utility should recruit staff with right skills and qualifications and train those with no right skills to better perform the given tasks in order to enhance organisation efficiency (Atafar, 2013).

Second, the study intended to determine the influence of financial resources on organisation efficiency of Mbeya UWSA. It was discovered that Mbeya UWSA depends on three sources of funds to finance day to day operations. The sources were government subvention, donor funds and bills collection from water supply and waste management services. Documentary review showed that out of the three sources, government subvention was the main source of finance to the utility. While government subvention was the main source of finance, the utility receives less than the actual budget. For instance, in financial year 2013/2014, the utility received only TZS $55,683,483(12.41 \%)$ with against actual budget of TZS 448,878,000/-. The budget deficit were to be covered through bills collection from the supply of water and waste water management. Through descriptive statistics, further analysis were carried out to determine the influence of financial resources constructs on the efficiency of the utility.

Table 5. Mean scores on financial resources influencing organisation efficiency

\begin{tabular}{clccc}
\hline S/No. & Financial resources constructs & $\mathbf{N}$ & Mean & Standard deviation \\
\hline 1. & Shortage of financial resources. & 30 & 3.57 & .817 \\
\hline 2. & Misuse of financial resources. & 30 & 2.93 & .868 \\
\hline 3. & $\begin{array}{l}\text { Lack of government priorities in } \\
\text { budgeting. }\end{array}$ & 30 & 3.73 & .583 \\
\hline 4. & Low rate of return in investment. & 30 & 2.90 & .662 \\
\hline
\end{tabular}

Table 5 shows that shortage of funds (3.57) and lack of priorities in budgeting (3.73) contributes moderately to organisation efficiency of Mbeya UWSA. This means that shortage of funds and lack of government priorities in budgeting affect organisation efficiency of the utility. There were great disparity between government budgets and the actual amount received by the utility. Similarly, misuse of financial resources (2.93) and low rate of return on investment (2.90) contributes to a small extent to organisation efficiency of Mbeya UWSA. These findings suggest that the utility obtains low rate of return on investment, due to low connection capacity to enhance waterbills collection which could increase productivity of the utility in service delivery. These findings support previous study by Mukokoma (2009) who found that most of water supply utilities are inefficient in bills collection. Further inferential analysis was carried out to determine the influence of financial resources constructs on organisation efficiency of Mbeya UWSA, using one sample $t$-test as summarized in Table 6.

Table 6. One-sample $t$-test on financial resources constructs and organization efficiency

\begin{tabular}{clcccc}
\hline \multirow{2}{*}{ S/No. } & \multirow{2}{*}{ Financial resources constructs } & \multicolumn{3}{c}{ Test value $=\mathbf{2 . 5}$} \\
\cline { 3 - 6 } & & $\mathbf{T}$ & $\mathbf{D f}$ & Sign.2 (tailed) & Mean difference \\
\hline 1. & Shortage of financial resources. & 7.149 & 29 & $.000^{*}$ & 1.067 \\
\hline 2. & Misuse of financial resources. & 2.733 & 29 & .011 & .433 \\
\hline 3. & Lack of government priorities in budgeting. & 11.581 & 29 & $.000^{*}$ & 1.233 \\
\hline 4. & Low rate of return in investment. & 3.311 & 29 & $.002^{*}$ & .400 \\
\hline
\end{tabular}

$* \mathrm{P}<0.05$ 
Table 6 shows that shortage of financial resources, lack of government priorities and low rate of return on investment were significant at $p<0.05$. This means that there is a difference in employees' perceptions regarding shortage of financial resources, lack of government priorities and low rate of return on investment to influence organisation efficiency of Mbeya UWSA. There was no difference in employees' perceptions regarding the misuse of financial resources construct as its $p$-value score was significant at $p>0.05$. This means that employees feel that there was minimal misuse of financial resources which could impair organisation efficiency of Mbeya UWSA. Following these findings, it can be concluded that there is a difference in employees' perceptions with regard to financial resources capabilities to influence organisation efficiency of Mbeya UWSA. This means that financial resources constructs influence organisation efficiency at 95\% confidence level. These findings are in line with Atafar (2013) who found that financial resources are important ingredients in enhancing organisation efficiency. In order to enhance organisation efficiency of water supply utilities in Tanzania, the government should put more priorities in its budget and ensure that budgeted funds reach the utilities on time. In addition, the government should devise a follow-up mechanism so that the allocated funds get used for the intended purposes. To enhance efficiency and sustainability of the service delivery, Mbeya UWSA should improve its capacity in bills collection and clients' connectivity in order to increase its financial base (Mashauri and Katko, 1993). This will eventually enhance not only its capacity to meet overheads and other investment projects but also it will improve the efficiency of the utility in customer service delivery.

Third and last, the study intended to determine the influence of physical resources on organisation efficiency of Mbeya UWSA. In the first stance, the study sought employees' perceptions regarding the quality of physical resources used by the utility. The findings revealed that $15(50 \%)$ of the respondents had no idea if the currently used physical resources were of good quality or not, $12(40 \%)$ were of the view that the physical resources used were not of good quality and outdated and $3(10 \%)$ were of the view that the physical resources used were of good quality and up-to-date. Moreover, the findings revealed that $21(70 \%)$ of the respondents perceived that the physical resources used were not enough, outdated and needed replacement, 6(20\%) of the respondents perceived the physical resources used were old but no need of replacement and 3(10\%) of them thought the physical resources were old and not sufficient to meet the growing demands of populations in the city.

Using descriptive statistics, further analysis were carried out to determine the level of employees' perceptions on each constructs as summarized in Table 7 below.

Table 7. Mean and standard deviation scores on physical resources constructs

\begin{tabular}{clccc}
\hline S/No. & Physical resources constructs & $\mathbf{N}$ & Mean & Standard deviation \\
\hline 1. & $\begin{array}{l}\text { Availability of modern working facilities used } \\
\text { for water supply. }\end{array}$ & 30 & 2.50 & .509 \\
\hline 2. & $\begin{array}{l}\text { The use of information and communication } \\
\text { technology in water service provision. }\end{array}$ & 30 & 3.00 & .371 \\
\hline 3. & Availability of modern office equipments & 29 & 2.59 & .568 \\
\hline 4. & $\begin{array}{l}\text { Availability of modern equipments for water } \\
\text { supply. }\end{array}$ & 28 & 2.57 & .573 \\
\hline 5. & $\begin{array}{l}\text { Engagement in survey and innovation in water } \\
\text { management. }\end{array}$ & 28 & 2.07 & .466 \\
\hline
\end{tabular}

Table 7 shows that the use of information and communication technology in water supply (3.00) contributes moderately to organisation efficiency of the utility. Availability of modern facilities for water supply (2.50), office equipments (2.59) and modern equipments (2.57) contributes to a small extent to organisation efficiency with mean score slightly equal to cut-off point. In order to enhance efficiency of the utility, the utility should procure modern physical resources such as computers, pipes, motors and other technical equipments (Ravangard et al., 2014). In similar vein, the utility should provide on the job training to employees in order to equip them with relevant skills on how to use such equipments to achieve the desired output. Engagement in survey and innovation in water management contributes to a very small extent with mean score below reference mean of 2.50 . This means that employees feel that little is done with respect to engagement in survey and innovation in water management. Further analysis using one sample $t$-test was carried out to supplement the descriptive findings. 
Table 8. One sample $t$-test on physical resource constructs and organisation efficiency

\begin{tabular}{|c|c|c|c|c|c|}
\hline \multirow{2}{*}{ S/No. } & \multirow{2}{*}{ Physical resources constructs } & \multicolumn{4}{|c|}{ Test value $=2.5$} \\
\hline & & $\mathbf{T}$ & Df & Sign.2 (-tailed) & Mean difference \\
\hline 1. & $\begin{array}{l}\text { Availability of modern working facilities used for } \\
\text { water supply. }\end{array}$ & .000 & 29 & 1.000 & .000 \\
\hline 2. & $\begin{array}{l}\text { The use of information and communication } \\
\text { technology in service provision. }\end{array}$ & 7.374 & 29 & $.000^{*}$ & .500 \\
\hline 3. & Availability of modern office equipments. & .817 & 28 & .421 & .086 \\
\hline 4. & $\begin{array}{l}\text { Availability of modern equipments for water } \\
\text { supply. }\end{array}$ & .660 & 27 & .515 & .071 \\
\hline 5. & $\begin{array}{l}\text { Engagement in survey and innovation in water } \\
\text { management. }\end{array}$ & .869 & 27 & .431 & .429 \\
\hline
\end{tabular}

Table 8 shows that the use of information and communication technology in service delivery was significant at $p<0.05$. This means that there was difference in employees' perceptions regarding the capacity of information and communication technology to enhance service delivery of the utility. This means that employees perceive the utility uses a well-connected information and technology infrastructures that aids service delivery. The remaining constructs had $p$-value scores significant at $p>0.05$ level. This means that there is no difference in employees' perceptions with respect to constructs' ability to influence organisation efficiency of the utility. This means that employees perceive that the constructs do not significantly contributes to organisation efficiency of the utility. Following these results, it can be concluded that physical resources had less influence on organisation efficiency of Mbeya UWSA. These findings are in line with Ravangard et al. (2014) who found that the efficiency of many organizations are affected by limited physical resources required to undertake specific tasks. It was also discovered that $70 \%$ of physical resources used were old and needed replacement and there was a shortage and $40 \%$ of them were not of good quality and outdated to cater for the high growing customers' demands of customers as fairly few customers were connected to the central system. It is a high time for the management of Mbeya UWSA to take deliberate initiatives to improve physical resources in order to enhance organisation efficiency of the utility.

\section{CONCLUSION}

The results from this study have shown that human resource competences in waste management, civil engineering, water pipes and other industrial services and agricultural water management contributes to a small extent to organisation efficiency of the utility. Shortage of financial resources, lack of priorities in government budget and low rate of returns in investment contributes to a small extent to organisation efficiency of the utility. The use of information and communication technology contributes moderately to organisation efficiency of Mbeya UWSA. Similarly, availability of working facilities, water supply equipments and engagement in survey and innovation in water management contributes to a small extent to organisation efficiency of the utility. About $70 \%$ of physical resources used were outdated and needs replacement to meet the growing demands of customers. In order to improve the efficiency of water supply utilities, deliberate efforts are needed to enhance clients' waterconnectivity. This will not only enhance the efficiency of the utilities in service delivery, but also their capacity to reach many clients as possible. In fact, many public water supply utilities have not fully exploited their capacity in customers' in-house water connectivity. It is a high time for water supply utilities to invest more on specific attributes that affect organisation efficiency in service delivery. Potential future area of study could be the influence of Non-Revenue Water (NRW) on organisation efficiency of water supply and sanitation utilities in Tanzania. Empirical evidences have shown that urban water supply utilities are wasting more than 70 million $\mathrm{m} 3 /$ per year of treated water before it reaches to final consumers. If converted into cash, it is more than 40 billion Tanzanian Shillings. However, fairly few empirical studies exist to substantiate the influence of NWR on organisation efficiency of water supply and sanitation utilities in Tanzania.

\section{ACKNOWLEDGEMENT}

The author would like to thank the management of Mbeya UWSA for their extended cooperation and logistics during data collection process. Special thanks should go to the entire employees who took their valuable time to respond to the questionnaire despite tight backlogs in their disposal. Without whose efforts, this study would not have been achieved. 


\section{REFERENCES}

Allen, D.G. (2008). Retaining talent: a guide to analyzing and managing employee turnover. USA: SHRM Foundation.

Atafar, A. (2013). Organizational factors affecting the efficiency of human capital: Business and management, 2(5), pp. $1-9$.

Doane, D.P. and Seward, L.E. (2011). Measuring Skewness. Journal of Statistics Education, 19(2), pp. 1-18. https://doi.org/10.1080/10691898.2011.11889611

Food and Agricultural Organisation (FAO) (2005). Aquastat Fact Sheet Tanzania. [online] Available at: http://www.fao.org/nr/water/aquastat/data/factsheets/aquastat_fact_sheet_tza.pdf [Accessed 13 Feb. 2016].

GIZ (2008). Water Supply and Sanitation Sector Reforms in Kenya, Tanzania, Uganda and Zambia: Challenges and Lessons, pp. 8-9. [online] Available at: http://www2.giz.de/dokumente/bib/GIZ2008-0361en-water-supplysanitation.pdf [Accessed 16 Apr. 2016].

Gopalakrishna, G. (2012). Factors influencing the effectiveness of efficiency of human resource management. Vietnam (pp. 135). [online] Available at: http://prr.hec.gov.pk/chapters/464s-4.pdf [Accessed 11 Apr. 2016].

Griliches, Z. and Regev, H. (1995). Firm Productivity in Israeli industry 1979-1988. Journal of Econometrics, 65, pp. 175-203. https:/ /doi.org/10.1016/0304-4076(94)01601-U

Hamilton, L.C. (1992). Regression with graphics. A second course in applied statistics. California: Wadsworth Inc.

Katundu, M.A. and Gabagambi, M. (2014). Entrepreneurial Tendencies of Tanzanian University Graduates: Evidence from University of Dar-es-Salaam. European Academic Research, 1(12).

Mashauri, D.A. and Katko, T.S. (1993). Water supply development and tariffs in Tanzania: From free water policy towards cost recovery. Environmental Management Journal, 17(1), pp. 31-39. https://doi.org/10.1007/BF02393792

Mjindo, M.D. and Laohasiriwong, W. (2015). Household Water Security and Related Factors in Mbeya Region, Tanzania. Proceeding of International conference on interdisciplinary research and development, 29 - 30 ${ }^{\text {th }}$ October 2015, Chiang May, Thailand, 29pp.

Muhairwe W.T. (2009). Making Public Enterprises Work: From Despair to Promise: A turn around account. London, UK: IWA Publishing.

Mukokoma, M.M.N. (2009). Application and effectiveness of New Public Management in National Water and Sewerage Corporation. Journal of Science and Sustainable Development, 2(1), pp. 15-23. https://doi.org/10.4314/jssd.v2i1.67559

Mwakalila, S. (2007). Residents' perception of institutional performance in water supply in Dar es Salaam. Physics and Chemistry of the Earth, 32, pp. 1285-1290. https://doi.org/10.1016/j.pce.2007.07.037

Ndunguru, P.C. (2007). Lecture on research methodology for social sciences (pp. 156). Research information and publication department, Mzumbe University, Morogoro, Tanzania.

Nickson, A. (2002). The limitations of water regulation: the failure of the cochabamba concession in Bolivia. Bulletin of Latin America Research, 21(1), pp. 1128-1149. https:// doi.org/10.1111/1470-9856.00034

Ravangard, R., Hatam, R., Teimourizad, A. and Jafari, A. (2014). Factors affecting the technical efficiency of health systems: A case study of Economic Co-operation Organization (ECO) countries (2004-10). International Journal of Health Policy and Management, 3(2), pp. 63-69. https://doi.org/10.15171/ijhpm.2014.60

Razali, N.M. and Wah, Y.B. (2011). Power comparison of Shapiro-Wilk, Kolmogorov-Smirnov, Lilliefors and Anderson-Darling test. Journal of Statistical Modelling and analytics, 2(1), pp. 21-33.

Semberya, D. (2013). Why water supply still poses problems in Tanzania? The Guardian Ippmedia.com. [online] Available at: http://www.ippmedia.com [Accessed 15 Apr. 2016].

Taheri, S. (1999). Productivity and its analysis in organizations: universal productivity management. (First Edition). Tehran: Dehestan Publication.

Tarizka, E. (2012). Organizational internal communication as the means of improving efficiency (pp. 182). Thesis for award of Master Degree, Guttmann Community College, New York.

UNICEF/WHO (2012). Progress on drinking water and sanitation: 2012 Update. New York: WHO/UNICEF Joint Monitoring Programme for Water Supply and Sanitation.

United Republic of Tanzania (URT) (2002). The National Water Policy. Ministry of Water and Irrigation. Dar es salaam, Tanzania.

United Republic of Tanzania (URT) (2007). Poverty and Human Development Report 2007. [online] Available at: http://www.repoa.or.tz/documents_storage/PHDR\%202007\%20Complete.pdf [Accessed 18 May 2016].

United Republic of Tanzania (URT) (2009). Water Sector Status Report 2009, Ministry of Water and Irrigation. [online] Available at: https://www.kfw-entwicklungsbank.de/migration/Entwicklungsbank-Startseite/DevelopmentFinance/About-Us/Local-Offices/Sub-Saharan-Africa/Office-Tanzania/Activities-in-Tanzania/WaterSector-Status-Report-2009.pdf [Accessed 22 May 2016]. 
United Republic of Tanzania (URT) (2010). Ministry of water and irrigation: Water supply and sanitation report, 2009 (pp. 69). Government printing office report, Dar es Salaam.

United Republic of Tanzania (URT) (2013). Tanzania in Figures (pp. 81). National Bureau of Statistics, Ministry of Finance, Dar es Salaam. Available at: http://www.nbs.go.tz/sensa/PDF/Census\%20General\%20Report \%20\%2029\%20March\%202013_Combined_Final\%20for\%20Printing.pdf [Accessed 20 Feb. 2016].

Van den Berg, C., Burke, E., Chacha, L. and Kessy, F. (2009). Public Expenditure Review of the Water Sector. [online] Available at: http://siteresources.worldbank.org/INTWAT/Resources/Tanzania-PER.pdf [Accessed 25 Jun. 2016].

Wallsten, S. and Clarke, G. (2002). Universal Service: Providing infrastructure services to rural and poor urban consumers. Policy Research Working Paper Series, 2868. https:/ / doi.org/10.1596/1813-9450-2868

WHO (2010). Global Water Supply and Sanitation Assessment Report 2010. Geneva: World Health Organization and the United Nations Children's Fund Publishing.

WHO/UNESCO (2013). Progression on Sanitation and Drinking Water. WHO Library Cataloguing-in-Publication Data. 